\title{
Broadening Our Horizons: Towards An Interdisciplinary Prehistory of THE ANDES ${ }^{1}$
}

\author{
David G. Beresford-Jones ${ }^{\mathrm{a}}$ \& Paul Heggarty ${ }^{\mathrm{b}}$
}

\begin{abstract}
This chapter sets out a new proposal for a coherent interdisciplinary prehistory of the Andes, based firstly on a long overdue reexamination of the relationships between the various regional 'dialects' within the Quechua language family; and secondly on the search for a far more satisfactory correlation with the archaeological record.

Our founding principle is that language expansions do not 'just happen'. Rather, they happen only for those very same reasons of socio-cultural change that archaeology seeks to describe through its own, independent data. Here is the true link between our disciplines, so we discard outdated, facile equations of 'language equals culture equals genes', in favour of the real correlation: that language families necessarily reflect past expansive processes, whose traces should also be clear in the material culture record. This principle is one that we can make use of to identify and assess correspondences between archaeological and linguistic patterns, on three levels: chronology, geography, and above all, causation. Or in other words: when, where and why did particular language expansions occur?

In the Andes, in principle this entails that we should look to the Horizons, not the Intermediate Periods, as offering the most natural explanations for the major Quechua and Aymara dispersals. With the Incas too late to account for the time-depth of either family, the most plausible candidate for the first major expansion of Quechua turns out in our view to be the Wari Middle Horizon, with the Chavin Early Horizon more tentatively suggested as behind the earlier spread of the Aymara family. This effectively both upturns the traditional Torero hypothesis, and bears clear implications for the long debate in archaeology as to the nature, duration and extent of 'Horizons'.
\end{abstract}

Keywords: Quechua, Aymara, Andes, Wari, horizon, Chavin, language families, language divergence

\section{Resumen}

AMPLIANDO NUESTROS HORIZONTES: HACIA UNA PREHISTORIA INTERDISCIPLINARIA DE LOS ANDES

Este artículo propone una nueva visión de la prehistoria andina, que busca tejer un conjunto más coherente entre las varias disciplinas que intentan entender el pasado precolombino. Se fundamenta, en primer lugar, en una reexaminación, pendiente ya desde décadas, de la clasificación tradicional de las relaciones entre los diversos "dialectos» regionales al interior de la familia lingüistica quechua; y, en segundo lugar, en la buisqueda de una correlación mucho más satisfactoria con el registro arqueológico.

El nuevo enfoque que aqui proponemos se enraiza en el principio fundamental que si algunas lenguas mayores han logrado dispersarse de manera espectacular, esto no pudo haber ocurrido sin ningún motivo. Más bien, tales expansiones lingüisticas se deben a las mismas razones —es decir, los mismos cambios socioculturales - que la arqueología también busca describir por medio de sus propios datos independientes. Alli radica el auténtico vinculo entre nuestras disciplinas, de manera que podemos descartar las ecuaciones simplistas y obsoletas del estilo "lengua $=$ cultura=genes", en favor de la correlación verdadera: las familias de lenguas

${ }^{a}$ Department of Linguistics, Max Planck Institute for Evolutionary Anthropology.

Dirección postal: Deutscher Platz 6, 04103, Leipzig, Alemania.

Correo electrónico: dgb27@cam.ac.uk

b Department of Linguistics, Max Planck Institute for Evolutionary Anthropology.

Dirección postal: Deutscher Platz 6, 04103, Leipzig, Alemania.

Correo electrónico: paul.heggarty@gmail.com 
reflejan procesos expansivos pasados, cuyos indicios deberian quedar claros también en el registro de la cultura material. Este principio se aprovecha para identificar y evaluar las correspondencias entre los patrones arqueológicos y lingüisticos, y asi en tres niveles: la cronología, la geografia y, sobre todo, la causalidad. En otras palabras: ¿cuándo, dónde y porqué se difundieron determinadas lenguas?

En los Andes esto implica que en principio debemos ver a los horizontes, y no a los periodos intermedios, como los que ofrecen las explicaciones más naturales para las dispersiones mayores del quechua y el aimara. Ya que el Imperio incaico remonta a una época demasiado tardía las explicaciones de la profundidad temporal de cada familia, es más bien el Horizonte Medio Wari el que se vuelve el candidato más verosimil para haber vehiculizado la primera gran expansión del quechua, según nuestro parecer. Asimismo, aunque de manera más tentativa, se sugiere que el Horizonte Temprano Chavín pudo haber impulsado la dispersión más temprana de la familia aimara. Esto, en efecto, trastoca la hipótesis tradicional de Torero, además de conllevar claras implicancias para el largo debate arqueológico acerca de la naturaleza, duración y extensión de los "horizontes».

Palabras clave: quechua, aimara, Andes, Wari, horizonte, Chavin, familias lingüisticas, divergencia lingüistica

Quando bien comigo pienso mui esclarecida Reina: i pongo deláte los ojos el antiguedad de todas las cosas: que para nuestra recordacion \& memoria quedaron escriptas: una cosa hállo \& sáco por conclusion mui cierta: que siempre la lengua fue compañera del imperio: $\&$ de tal manera lo siguió: que junta mente començaró. crecieron. \& florecieron. \& despues jũta fue la caida de entrambos².

Antonio de Nebrija, Gramatica de la lengua castellana, 1492

\section{Great Language Expansions Do Not 'Just Happen'}

Ernst Middendorf, Max Uhle, Julio C. Tello, and John H. Rowe, the great pioneers of Andean archaeology, could confidently distinguish 'horizons' in the vast archaeological record they surveyed: periods for which that record showed some degree of unity or interaction across great expanses of the Central Andes. Each of three successive horizons originated high in the Andes (see Heggarty \& Beresford-Jones, this volume: Fig. 1). The Late Horizon was of course the Inca Empire, stretching from Ecuador to Argentina and Chile, with its capital in Cuzco in the southern highlands of Peru. The Middle Horizon, meanwhile, had been a bipolar affair: a Wari 'Empire', with its heartland in Ayacucho, south-central Peru; and a more vaguely perceived sphere of influence of Tiyawanaku ${ }^{3}$, by the shores of Lake Titicaca in the Bolivian Altiplano. The Early Horizon is even less clearly defined, but since the days of Tello many would centre it on the monumental site of Chavín de Huántar in Áncash, north-central Peru. Between the horizons were the intermediate periods, for which the archaeological record is, by contrast with the horizons, more fragmented and localised.

At first these horizons were often imputed to expansionist military conquest: empires akin to that of the Incas. In time, however, archaeologists became uncomfortable with such uncritical analogy. Moreover, they turned their attention to working at higher resolution, on smaller scales: seeking to track processes of culture evolution within tightly-circumscribed geographical regions. As they did so, the earlier grand scales of analysis fell from grace. Increasingly questions were asked about the precise extents and natures of the putative horizons: the Middle and Early Horizon "problems", as they now became (Schreiber: 1992: 71, Willey 1951: 103). Many of these questions have yet to be resolved. Indeed for some these doubts undermine the very utility of the horizon idea itself, such that Boone (1993: vii) could go so far as to opine that "in the end, the judgement is that the horizon concept is too broad and simple for the scholar, but that it is useful for the student".

Yet the concept of the horizon stubbornly persists in Andean archaeology. Almost twenty years ago, for instance, Burger (1993: 41) acknowledged that "the concept of horizon style has fallen out of fashion in North American archaeology" — but nonetheless went on to insist that "the Chavin horizon is not a stylistic chimera as some have contended, but a real pattern" (Burger 1993: 74). We too shall argue in this paper that the horizon concept does indeed retain value in Andean archaeology; not least in how it underlies a new proposal we set out here on how best to link the different but complementary records of the 
past that lie in the archaeology and the languages of the Andes. It is perhaps no surprise that Middendorf, Uhle, Tello, and Rowe were either also linguists themselves, or deeply persuaded of the utility of linguistics for understanding Andean prehistory (see Burger 2012).

The founding principle behind our proposal is the simple observation that language expansions do not just happen. Rather, they happen only for those very same reasons of socio-cultural change that archaeology seeks to describe through its own, independent data, the material culture record. We discard outdated, facile equations of 'language equals culture equals genes', in favour of the real correlation: that language families necessarily reflect past expansive processes, whose trace should also be clear in the material culture record.

There follows from this also a principle of commensurate scale on either side of this language - archaeology link: great language dispersals must have been driven by real-world processes of corresponding import and impact. The expanse of the Romance language family, for instance, from the Black Sea to the Atlantic, is none other than the linguistic reflex of the strength and lasting impact of Rome. The Central Andes, meanwhile, host two major language families - Quechua and Aymara — behind which lie processes of expansion that did not take place in some social and demographic vacuum. This principle is one we can make use of, to identify and assess correspondences between archaeological and linguistic patterns on three levels: chronology, geography, and, above all, causation. Or in other words: when, where and why did particular language expansions occur?

Moreover, as explained in Heggarty \& Beresford-Jones (this volume), there are two linguistic processes in play. These are in fact all but the reverse of each other, but both in their different ways leave signals of past associations between the populations that spoke given languages: whether of divergence, or convergence. The distinction proves particularly instructive in the Andes, because the exceptional convergence between the two major language families sets another, independent explanandum that any coherent picture of Andean prehistory needs to account for.

A coherent model of Andean prehistory must therefore explain satisfactorily the patterns of correspondence both within each of the two major Andean language families, and also between them. Simultaneously, it needs to match with the independent archaeological record on all three levels of chronology, geography, and causation. We have set out in Heggarty \& Beresford-Jones (this volume) why we consider that none of the proposals so far conceived, whether by linguists or by archaeologists, yet engages smoothly with all these constraints together. (Those proposals include the popular myths that the expansions of Quechua and Aymara are the inheritances of the Incas and Tiyawanaku respectively. For as we stress in Heggarty \& Beresford-Jones (this volume), each of those myths flouts, to varying degrees, principles of compatible chronology and geographical distribution, while simultaneously failing to explain in any way the correspondences between these two language families.) So in this chapter we propose a new key to unlock the conundrum of Andean prehistory, founded firstly upon a re-examination, indeed reclassification, which we feel is long overdue, of the relationships between the various regional languages and 'dialects' within the Quechua language family; and secondly on the search for a far more satisfactory correlation with the archaeological record. We first briefly outline our proposal in $\$ 2$, before explaining in detail the reclassification of Quechua that underlies it in $\$ 3$, and then in $\$ 4$ assessing how the repercussions feed back into our understanding of Andean archaeology.

\section{Linking Archaeology and Linguistics in the Andes: A New Proposal}

We start out from the prima facie logic that it is the horizons in Andean prehistory, not the intermediate periods, that offer by far the best evidence of significant geographical expansions of people and ideas, and thereby the best candidates for drivers to account for the major language expansions too. Regardless of one's position on the many important debates within archaeology as to what were the driving forces behind these horizons, and their exact extents, we suppose here that one broad-scale observation still stands: the horizons are manifestly different from the intermediate periods.

Indeed, we should clarify how we use the term 'horizon' here, for different scholars have taken it in two different senses, focusing either on the distribution of a material culture style, or on a phase in chronology during which that style appears (see the discussions in Silverman 2004: 11-14, and in McEwan 2012). 
Originally, the geography-chronology match was thought to be so consistent that the two were effectively synonymous, and the stylistic horizons could thus be taken also to define fixed blocks of time, valid for all the regions concerned together. Naturally though, in practice stylistic horizons vary considerably from place to place in how and when they manifest themselves in the material culture record. Archaeologists working at ever-finer time-scales and within more limited geographical areas have become increasingly sensitive to these variations. Much of the radiocarbon evidence on Wari now falls outside Rowe's original chronological specification of the 'Middle Horizon'. We need to progress to a more sophisticated and flexible definition: one that accepts that a horizon can apply over different time-spans in different areas, though without that undermining the essential unity of the phenomenon. In concepts such as the 'Roman Empire' or 'the spread of Islam' the same subtlety is of course implicit, and widely understood and accepted. It is in this more sophisticated sense of core geographical and chronological overlaps that we employ the terms 'Chavín Early Horizon' and 'Wari Middle Horizon' herein.

The Andean archaeological record shows three horizon epochs, while its linguistic record reflects just two major language dispersals. For the reasons discussed in Heggarty \& Beresford-Jones (this volume), however, we can rule out the Late Horizon as too late to account for the main expansions of either Aymara or Quechua. Thus we are left with a strikingly straightforward picture of two horizons and two language dispersals. Our proposal overturns the traditional model's vision of the Wari Middle Horizon as Aymaraspeaking, and associates it with the dispersal of Quechua instead. In principle this would then leave the Chavín Early Horizon as a logical candidate to account for the (apparently preceding) Aymara spread. The evidence at these greater time-depths is necessarily far weaker, but an Aymara-Chavín association at the very least merits exploration as a starting hypothesis, and one for which we shall therefore also attempt here to make the case, alongside the strong Quechua-Wari association.

On the one hand, we see the apparent simplicity of this proposal as its great strength: it satisfies Occam's injunction by providing the most parsimonious match between the relative strengths and timings of the key socio-cultural and demographic driving forces in Andean prehistory (Chavín and Wari), and the two great language family expansions that linguistics looks to such forces to explain (Aymara and Quechua). On the other hand, viewed from the limited perspective of a single discipline, simple might all too easily be confused with 'simplistic' — for instance, by those archaeologists conscious of just how much debate in fact surrounds the chronology of Andean prehistory and the true enature of these horizons. And yet, the real strength of this proposal is not only that it satisfies broad correspondences with the archaeological record on all three levels of chronology, geography and causation, but also that it simultaneously explains the correspondences both within each of the two major Andean language families (their respective divergence histories), and also between them (their intense convergence). In suggesting a solution to a conundrum posed concomitantly by data from both disciplines, we venture that our scenario turns out to be in fact rather less simplistic than any of the alternatives proposed so far, by either linguists or archaeologists of the Andes.

We next set out the framework within which we seek to bring together the linguistic and archaeological records in the Andes, on the levels of chronology, geography and causation. Along the way, we clarify precisely how our proposal explains each of the different aspects of divergence and convergence within and between the Quechua and Aymara families.

\subsection{Chronology}

Firstly, associating Aymara with the Early Horizon is in line with those indicators we do have that suggest that Aymara expanded earlier than Quechua (see Heggarty 2007: \$4.4, 2008: \$3.2). More significantly, the chronology of our proposal would have Aymara dispersing widely with the Early Horizon, out of its Chavín homeland. The prestige associated with it would, in the Ayacucho region, exert on the pre-protoQuechua language spoken there at the time a powerful 'superstrate' influence - whereby speakers of a lower-status language refashion aspects of it on the model of a higher-status one with which they come into contact. (For a comparison of various forms of language contact context, and their expected linguistic results, see Muysken 2012.) Yet Chavín influence would ultimately wane, and centuries later this newly remodelled Quechua would undergo its own expansion, carried by the same processes that have left us the 
archaeological record of the Wari Middle Horizon. And as it spread, Quechua would 'overwrite' the earlier dispersal of Aymara, to leave it surviving only in small isolated highland pockets across its original range in central and southern Peru.

We envisage, then, a heavy Aymara superstrate impact on the language ancestral to the entire Quechua family, which then in turn expanded across Aymara's previous extent. This pattern would better explain the particular form and strength of the convergence between the two families than does the traditional model's vaguer proposal, of simply 'adjacent' homelands for ancestors of both families. Indeed, their convergence is often explicitly described in terms of one of the two being restructured in the image of the other (e.g. Cerrón-Palomino 2000a: 337), though different views are expressed on which 'remodelled' which (see Muysken 2012).

\subsection{Geography}

On the level of geography, the linguistic data are, as Adelaar \& Muysken (2004: 263) put it, "not incompatible with the alternative hypothesis of an original Aymaran homeland further north, in the heart of central Peru itself". Our association of Aymara with the Early Horizon would put that homeland in the central highlands of Áncash, centred on its core site of Chavín de Huántar. Cerrón-Palomino (2000a: 378) reports 'significant' Aymara toponymy across precisely this region of central Peru. His inspection of toponymic dictionaries (Cerrón-Palomino 2003: 292-293) "indicates the presence of such elements diagnostic of Aymara in the departments of Lima, Junín, Pasco, Huánuco, Áncash, and to a lesser degree, in La Libertad, Piura and Cajamarca" - respectively, we note, the core and periphery of the Early Horizon (see Heggarty \& Beresford-Jones, this volume: Fig. 4). On the chronological sequence of the language presence in Central Peru, nowadays Quechua-speaking, we stress Cerrón-Palomino's further specific observation that these placenames and other linguistic evidence provide "indirect evidence of the presence of a prior Aru [Aymara] substrate [in Áncash]" (Cerrón-Palomino 2003: 333, our translation).

Outside its Áncash heartland, the frontiers of the Early Horizon (so far as they existed) remain to be precisely determined. On the coast, distinctively 'Chavinoid' material culture extends as far south as the Ica and Nazca river drainages. In the highlands, meanwhile, a major Chavín site is currently being excavated at Campanayuq Rumi near Vilcashuamán, 60 km south-east of Ayacucho (see Burger 2012: 140). This southern limit of the Early Horizon is thus entirely consistent with an Aymara superstrate 'remodelling' the language ancestral to the Quechua family, as explained in Heggarty \& Beresford-Jones (this volume: $\$ 3$ ), and as per Muysken (2012). It also takes Aymara far enough south to be at least within plausible range of what would become its southernmost regions: Cuzco, and eventually — by much later expansive processes over a millennium later, by which time it had developed into its distinctive southern variety - the Altiplano. Strikingly, again on the level of toponymy, several of the placenames just mentioned lend themselves to convincing Aymara etymologies, not least Ica, Vilcashuamán and Cuzco itself (Cerrón-Palomino 2008, and personal communications).

For the Wari Middle Horizon the geographical correlation is even stronger between its archaeology and the historical linguistics of Quechua. As we shall shortly see, there are several starkly contrasting interpretations of the archaeological record for the Middle Horizon. But for our purposes here, at least "most researchers agree that Wari was an expansive state, an empire that consolidated power rapidly", as Cook (2004: 146) puts it.

The Wari heartland lay in the Ayacucho highlands of the south-central Andes, centred on the eponymous urban centre there. The consensus would have Wari expanding rapidly out of this region during its so-called Epoch 1B, to control directly the central and southern coast between Chancay and Acarí, and the Peruvian highlands over an even greater extent, from Áncash to Sicuani: see Figure 1 and Menzel (1967: 147). At its apogee around $\mathrm{AD} 800$, its capital at Wari was vast, covering some $15 \mathrm{~km}^{2}$. It remains to this day the largest archaeological site in South America (Isbell et al. 1991: 24).

We have not the space here to review in any detail the evidence or associated controversy behind this model of a Wari Empire. Suffice it to say that it includes the identification of permanent Wari administrative architecture, exemplified by the site of Pikillaqta in the Cuzco region (see Figure 2; Isbell 1987; McEwan 1991, 2012; Schreiber 1992, 2000); distributions of mobile Wari material culture (Menzel 1967); 

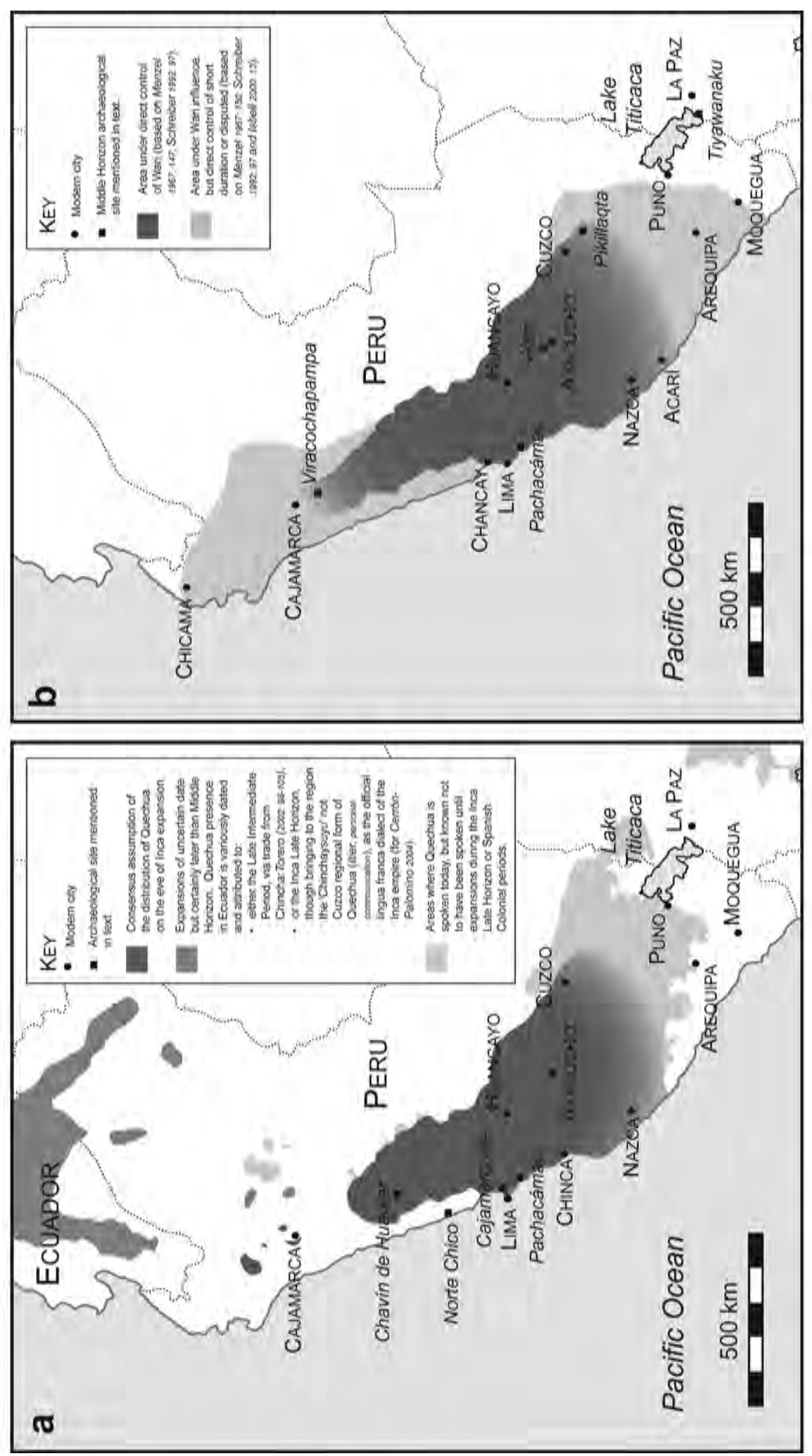

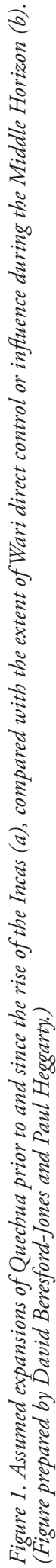




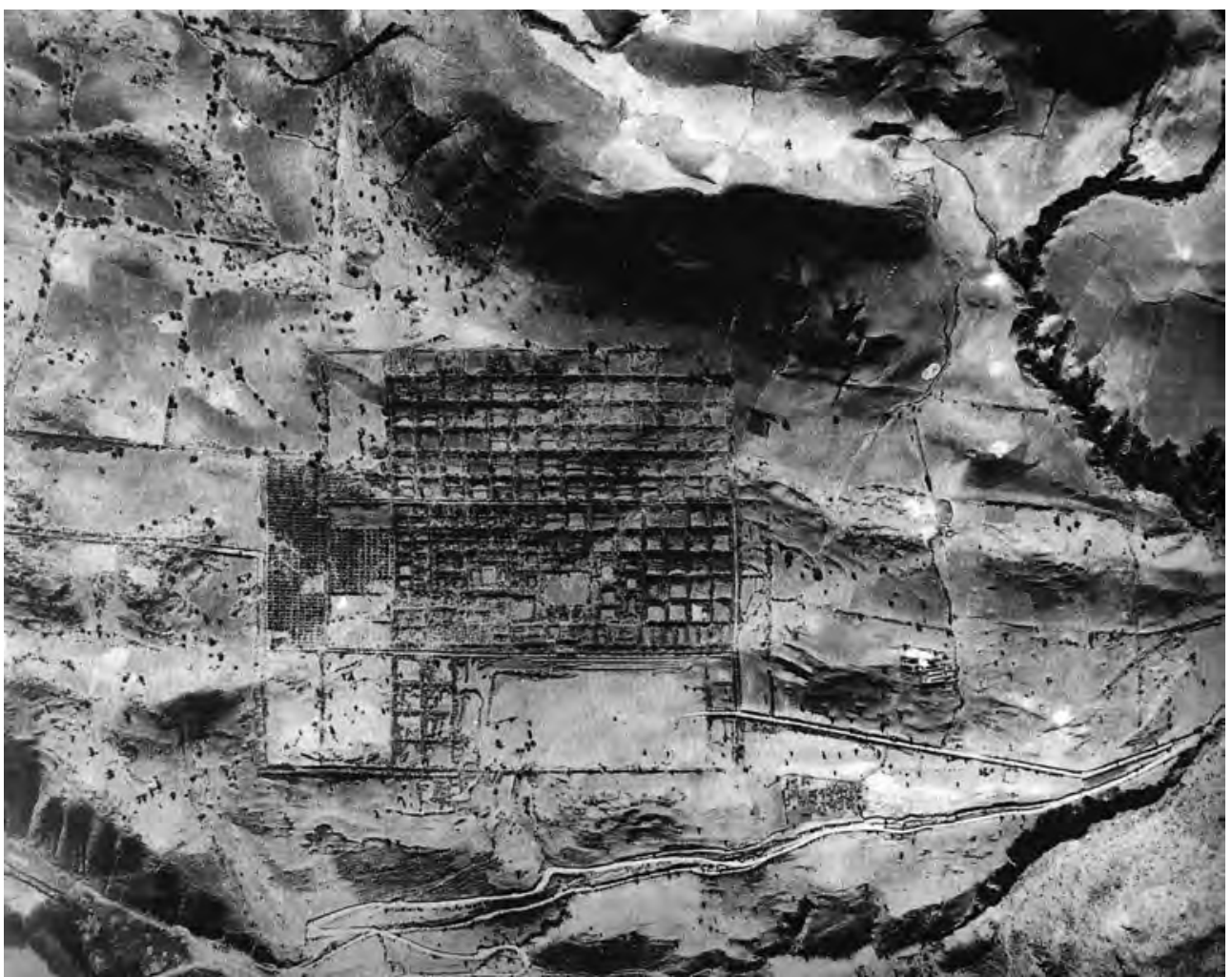

Figure 2. Aerial view of Pikillaqta, a Wari outpost south-east of Cuzco: "such incredibly regimented planning ... is not otherwise known in the world history of human environments" (Conklin 1991: 287). Courtesy of the Servicio Aerofotográfico Nacional, Peru.

evidence that much of the Inca road network was rehabilitated from an earlier Wari system (Lumbreras 1974); Wari antecedents of the Incas' khipu knotted-string accounting device, firmly dated now to the Middle Horizon (Urton 2012); and even fragmentary hints in ethnohistory (Hiltunen \& McEwan 2004). Such evidence is deployed to support a model of 'direct control' by Wari of the vast area of central and southern Peru defined above (Schreiber 1992; D’Altroy \& Schreiber 2004; Isbell 2012, this volume). Further north, beyond Áncash and into La Libertad and the Cajamarca basin, evidence for that direct control becomes fragmentary. There are scattered sites here that have long offered tantalising hints of Wari administrative architecture (Schreiber 1992: 96, Watanabe 2002, Adelaar 2012), and are duly steadily emerging as such on fuller investigation (Watanabe, this volume). On the densely-populated north and north-central coasts, meanwhile, with their own long, independent prehistoric trajectories, evidence for Wari's presence is much more ambiguous - limited to mobile material culture and mortuary remains, leading archaeologists to infer only 'indirect control' or influence (D’Altroy \& Schreiber 2004).

South of the Cuzco region, Wari confronted the other major pole of the Middle Horizon: Tiyawanaku in the Titicaca basin. The archaeological story behind the Wari $\sim$ Tiyawanaku relationship is another subject of considerable complexity. So similar is their iconography that both were initially conflated under the label 'Tiahuanacoid'. Clearly both partook of a shared ideological tradition, widespread across the southcentral Andes and which dates back to the Early Intermediate or even before (Isbell \& Knobloch 2008). Yet ever since the days of Rowe, the two have been recognised as having spheres of influence over territories mutually exclusive (Figure 1b), and entirely distinct trajectories in all aspects of their economy and society (Conklin 1991, Schreiber 1992, Isbell \& Vranich 2004). Indeed, the evidence from around Cerro Baúl (Moquegua, S.E. Peru) suggests that their relationship was often one of open military conflict (Moseley et al. 1991, Isbell 2000, Williams \& Nash 2002). 
How does this geographical extent of the Wari Middle Horizon compare with that of the Quechua language family? We observe a remarkably close correlation between them. As already discussed, in many regions linguistics can reliably identify those parts of the Quechua expansion that clearly date to periods more recent than the Middle Horizon. Quechua reached Ecuador either during the Late Intermediate or (Hocquenghem 2012) in the Late Horizon, and perhaps expanded further there during the colonial period. Likewise it spread into Bolivia and north-west Argentina with the Incas and in the early colonial period (see Adelaar 1995, DeMarrais 2012). Finally, it has extended down the eastern flanks of the Andes into the Amazon especially from colonial times onwards.

On the other hand, it has long been appreciated that other parts of Peru where today no indigenous languages survive - in particular the south-central coast — were specifically Quechua-speaking at the time of Spanish conquest, and indeed had been well before the Incas too (Cerrón-Palomino 2003: 327-8). Once these later expansions and disappearances are respectively stripped away from and added back to the map of Quechua's current distribution, we are left with a map bearing a strikingly close resemblance to the extent of the Wari Middle Horizon (Figure 1). Quechua dominates the highlands of Peru from Áncash in the north towards Cuzco in the south. Further north in the highlands it persists - and seems only ever to have been present - in just a few isolated pockets in Cajamarca and highland Lambayeque, within wider regions that previously spoke a patchwork of non-Quechua languages. And while Quechua dominated the south-central coast, north of Lima it never gained much foothold among the densely populated valleys of the north coast.

The only part of the map that shows uncertain correspondence with the Wari Middle Horizon is that area of the southern sierra towards the Titicaca basin that is Quechua-speaking today but lies somewhat beyond the southern limits of where archaeology would define Wari's influence, and where it abutted on the Tiyawanaku sphere (see for instance Williams \& Nash 2002, Tung \& Owen 2008). Yet here too linguistics tells a revealing tale, for the region is seen as a 'linguistic battleground' where Quechua's predominance over Aymara came rather late in prehistory, perhaps only during the Inca Late Horizon and early Spanish control (Cerrón-Palomino 2012).

\subsection{Causation}

Striking as these correspondences in chronology and geography may be, they are but circumstantial evidence for our core case. Its real strength lies on the level of causation. We reiterate the axiom of our approach: language expansions do not 'just happen', they happen only for those very same reasons of real human demography and socio-cultural context that archaeology seeks to perceive through the material culture record. And great language dispersals like those of Quechua and Aymara can only have been driven by processes of commensurate scale.

For our proposal to stand we need not attempt to link the expansions of these language families in the Andes to particular 'cultures', nor indeed infer their association with the spread of a particular 'people' and their genes. In our approach we seek to link them through expansive processes; and the only ones of commensurate scale evident in the archaeological record of the Andes are those associated with the horizons.

Quechua has long replaced Aymara throughout Peru, save for the southernmost strip bordering Bolivia (Altiplano or Southern Aymara), and the tiny central highland enclaves of Jaqaru-Kawki (alias Central Aymara). All other indigenous languages are extinct from highland Peru. Quechua's early expansion closely matches that of the Wari Empire. (Even today the most heavily Quechua-speaking region is that of Ayacucho, the heartland of Wari.) And while archaeologists have proposed very different interpretations to explain the material culture record left by the Middle Horizon, all have in common an agreement that the period was characterised by major social change and upheaval: in short, a far more plausible context for language expansion and replacement than the periods of at least relative regional stasis that preceded and followed it.

The size, complexity and poor state of preservation of the site of Wari itself have defied comprehensive archaeological survey to date (Isbell 1988: 167). Speculative population estimates for the city range between 50,000 to 100,000 (Benavides 1991: 56), or 20,000 to 34,000 (Isbell 1988: 173). Whatever, it was by any measure an enormous ancient city: even half a millennium later, Venice, the largest city in Europe, 
had a population of under 50,000 (McEvedy 1992: 75). Survey data indicate how the populations in surrounding areas were gradually drawn into the vast agglomeration that was Wari (Schreiber 1992: 88, Isbell \& Vranich 2004: 177).

Furthermore, the archaeological record indicates movements of people across the Andes on a far largerscale during the Middle Horizon than in the Intermediate Periods that came before and after it. Mobile material culture indicative of Wari influence is distributed throughout the highlands and along the southcentral coast of Central Peru, save for the very far south (see Figure 1b and Menzel 1967). Sites in the Cuzco region, meanwhile, and Wari itself, have yielded significant quantities of ceramics from Cajamarca, almost 1,000 km to the north. As Menzel (1967: 152) observes, "their abundance [at Wari itself] is such as to suggest that there were colonies of northerners established at the imperial capital". In non-mobile material culture, for Isbell (1987: 86) "perhaps the dominant feature of Wari architecture" is that of "barrackslike residential facilities", interpreted as housing for mobile labour or military personnel (see also McEwan 1991: 117). D'Altroy \& Schreiber (2004: 274) summarise the consensus view thus: "it is now clear that these sites were occupied by large numbers of people, both foreigners from Wari and local peoples". And some of these sites were huge. Pikillaqta, for instance, was but a part of the intense Wari occupation of the Cuzco region (Figure 2, McEwan 1991, 2012; Glowacki 2002). Yet this single component of the Wari periphery in fact covers an area greater than the later Inca imperial capital of Cuzco (McEwan 1991: Fig. 2).

There is strong evidence also that the Wari Middle Horizon was, in large part, based upon the intensification of food production in the intermontane valleys of the highlands: the 'quichua ecozone'. The extent of Wari direct control seems intimately associated with this zone - the same area over which Quechua saw its first major expansion, and from which, incidentally, it acquired its very name. (See Cerrón-Palomino 2008: 33-49, however, for a path through the minefield of popular myths surrounding the etymologies of the terms Quechua and Aymara.) The evidence includes: large-scale shifts in settlement, and in subsistence regimes from tubers to maize cereals; the introduction of new maize varieties (Grobman et al. 1961, Bird et al. 1984); and construction of terracing on a huge scale (Schreiber 1992, 2000). All appear to have been instigated by some form of 'state' in order to supply distant urban populations. Isbell (1988: 182) credits the Wari Middle Horizon with the development of a uniquely Andean form of "state finance" — what Godelier (1977: 188) had first called the "Inca mode of production" — whereby long-standing local traditions of reciprocal exchanges of labour were elaborated into a system of labour-taxation, in exchange for food and drink provided at state-sponsored feasts. Much Wari iconography, particularly on gigantic ceramic vessels associated with feasting, reflects an apparent preoccupation with agricultural themes (see for instance Shady 1989: 13). Indeed, some see the innovations wrought by Wari in these respects as so fundamental and enduring that they defined the course of subsequent Andean civilization (Isbell 1988: 182), and settlement patterns even to this day (Schreiber 1992: 260, Williams \& Nash 2002: 255).

We argue here that so too did they define major patterns in language expansion and distribution. Indeed, that Quechua was later adopted by the Incas as the language of administration for their empire was not because it was their own original tongue. Rather, there are strong indications that the Incas themselves may well originally have spoken Aymara, and switched their 'official' language of empire to Quechua only relatively late in their trajectory of imperial expansion, during the reign of Tupac Inca Yupanqui (1471-1493). Their reason may have been an entirely pragmatic one: that most northern lands that fell to the Incas were already speaking Quechua, precisely because the earlier Wari Empire had so dramatically spread it there. It even appears that the form of Quechua the Incas selected for this purpose was not that ultimately spoken in the Cuzco region, but a more northerly 'Chincha(suyo)' version. For details on all of these issues, see Cerrón-Palomino (1998, 1999, 2003: 342, 2004, this volume).

As for the longevity of the Wari Middle Horizon, Menzel's original relative chronology based only on ceramic typology would have us believe that its rise and fall were swift. As Schreiber (1992: 276) puts it: "each phase of the Middle Horizon 1B, 2A and 2B, is estimated to have lasted only about 50 years ... If this accurate, the Wari Empire lasted only about 150 years". Yet in the face of mounting radiocarbon evidence (see for instance Williams 2001), this view has now been abandoned. As Cook (2004: 158) summarises: "instead of a 200-year span (approximately AD 650-850) during which time the empire flourished, the time frame has doubled (approximately AD 550-1000)". This relatively recent understanding that the 
time-depth of the Middle Horizon approached half a millennium is far more compatible with the dramatic linguistic impact that our proposal would attribute to it.

\subsection{Geography, Chronology and Causation: the case of Aymara}

What, then, of the other great language family of the Andean past, Aymara? Again, any coherent prehistory must hold together simultaneously on the levels of geography, chronology, and above all causation; while also accounting for Aymara's remarkable correspondences with Quechua. What this entails is that the apparent coincidence — at first sight so beguiling — between Aymara’s surviving modern distribution, limited now almost entirely limited to part of the Bolivian Altiplano, and the ancient sphere of influence of Tiyawanaku, is in fact misleading and anachronistic. (For more details, see Heggarty \& Beresford-Jones, this volume: $\$ 1$ ). A match on the level of geographical distribution alone means little.

Altiplano Aymara of course has great prominence in popular perception today, which imagines this language lineage only ever to have been spoken here, for being unaware of its relatives elsewhere. Yet in reality the Aymara of the Altiplano represents but a fraction of the family's former extent, which once reached at least as far as northern parts of the Lima department. Likewise, the Altiplano hosts but a fraction of the scale of diversity within the Aymara family: on the measures in Heggarty (2005), modern Altiplano varieties amongst themselves register about $10 \%$ variation in basic vocabulary, as opposed to some $45 \%$ vis-à-vis the Aymara languages of Central Peru.

Even within Bolivia, its surviving heartland, in demographic terms Aymara is greatly outnumbered by Quechua speakers (see Table 8.5 in Howard 2011). And the latter themselves represent the demographic legacy of the Incas and Spaniards (particularly through the Potosí labour draft) in just this one part of their respective Empires in the Andes. Altiplano Aymara is not remotely as significant as the spread of the Quechua family as a whole; on the contrary, it is directly equivalent to just a small sub-part of it, such as the Quechua of Bolivia alone.

So in the context of our principle of commensurate scale, the Aymara of the Altiplano does not in fact represent a particularly spectacular language expansion, nor is it a very old one. It is but a fraction of the family's major dispersal that prehistory is really called on to explain, and a relatively late addendum to it. Any hypothesis for its spread here must moreover concur with both the rather late chronology inherent in the relative lack of diversity in the Aymara spoken there today, and with the persistence of other, unrelated indigenous languages until well into the post-Colombian period (Puquina), indeed even to this day (Uru-Chipaya).

This question of quite which (combination of) real-world circumstances might best account for the modern Aymara presence on the Altiplano lies beyond our purposes here; we therefore reserve our exploration of it for later publications. But to summarise the most plausible explanations, they might include: the 'vacuum' left by a putative (mostly Puquina-speaking?) Tiyawanaku population collapse; imperial policy in the early expansions of the Incas (at the time Aymara-speaking, at least for Cerrón Palomino 1998, this volume); and then further support from the impacts of Spanish evangelisation in Qullasuyu.

This is hardly to deny that the Aymara family as a whole did once undergo great expansion, through much of the southern half of Peru and (at least to follow Cerrón-Palomino 2000: 377-378) even further north though the central highlands. That is the great Aymara dispersal that prehistory is called upon to explain by some particularly powerful expansive process, rather than its relatively minor, later intrusion into the Altiplano. To account for that first, greater and deeper Aymara dispersal, we look instead tentatively to the Early Horizon, even if both the archaeological signature and the linguistic traces are naturally far fainter. In linguistics, no language expansion has to date been explicitly attributed to the Chavín Early Horizon. It is true that Cerrón-Palomino's (2003: 22) reflections on a Quechua homeland in the central highlands, not the coast, might at least hint at Chavín as a possible candidate. While his claims to this effect now appear to be strengthening in response to our own hypothesis (see Heggarty \& Beresford-Jones, this volume: $\$ 4.2$, Cerrón-Palomino, this volume), even he had been reluctant hitherto to formalise such a claim. Such reluctance on his part was presumably based on the same objection that most other writers see: the Early Horizon seems just too far back in time to correspond with the expansion of so shallow and compact a family as Quechua. On this last point we could not agree more, but it remains problematic in 
the traditional thinking that such a defining archaeological signal as the Early Horizon is left without any significant linguistic correlate, when the linguistics is crying out for a driver for Aymara — and, it would appear, before the spread of Quechua.

In the end, however, given its far fainter traces, our association of the Early Horizon with the expansion of Aymara on this level of causation relies also on reductive reasoning. If our proposal to ascribe Quechua to the Wari Middle Horizon stands, then our axiom associating major language family expansions with horizons leaves us left with one such expansion to explain in the Andes, and only the Early Horizon to explain it with. It fits, moreover, with the clear indications that over almost all its core range in Peru, Quechua seems to overlie an earlier Aymara spread. Indeed as explained in $\$ 2.1$ above, such a model — whereby an expansive Aymara first impacted on the original Quechua homeland in the Ayacucho region, 're-working' their language in situ — can at the same time plausibly account for the intimate correspondences between these two language families, and their particular nature, back to a very early stage in Quechua's history, long before it began its own great expansion during the Wari Middle Horizon.

\subsection{Agricultural Intensifications and 'Language Horizons'?}

This reflection brings us on to what is in some senses an even more fundamental prior question. How come the Andes, unlike most other regions of the world, do not host any identifiable wider language families whose expansions go back much earlier in time than the relatively shallow families that are Aymara and Quechua? At this deeper stage in the chronology, but focused above all on the question of causation, there is of course one highly controversial hypothesis that would see the expansions of a number of the largest, deep-time language families around the world as having been driven essentially by the spread of farming. Particularly from that perspective, though, the distinctively shallow time-depths of the great Andean language families would seem strange, given the region's status as one of precious few independent hearths of agriculture worldwide.

Elsewhere (Heggarty \& Beresford-Jones 2010), we have argued that a number of important idiosyncrasies in the Andean context, which led agriculture to develop here in ways very different to the Old World, may thus explain why the linguistic story here also looks so different. For the Andes are characterised by: (a) extreme topographical and ecological diversity, from coastal desert to high-altitude tundra to Amazonian rainforest; (b) few large mammals, with only camelids domesticated; (c) exceptionally rich marine resources, such that fishing could provide an alternative form of protein; and (d) no true cereal crop until maize arrived, relatively late and apparently from Meso-America. (For further details, see Heggarty \& Beresford-Jones 2010.)

Our own suggestion, then, was that despite the very early origins of farming here, these idiosyncrasies of the Andes conspired to postpone when developments would eventually come together here into an expansive, cereal-based 'agricultural package'. Not until some three thousand years ago did agriculture in the Andes cross this critical threshold of intensification, which does at last bring us into the earliest limits of plausible date-ranges for the Aymara and Quechua language dispersals (Figure 3). Simultaneously, the archaeological record detects the first 'horizon' across the region — and the first unequivocal evidence for the appearance of maize in the Peruvian archaeological record in Peru (Pearsall 2008: 106, Fig. 7.1). Could it be that this change was significant enough to have fed a population expansion (cf. Sutter 2009), and with it a language spread too, following the demography/subsistence model of language replacement presented by Renfrew (1989, 2012)? Isbell (this volume) reasserts precisely this link between maize agriculture and the expansion of the Quechua language family. In so doing he was renewing his own insightful proposal to the same effect, as early as Isbell (1974), though amending its context by drawing now upon our new hypothesis. In short, he maintains the maize - Quechua link, but shifts its chronology forward, and its geography southwards and into the highlands, so as to match now with the Wari Middle Horizon.

As we have seen in $\$ 2.3$ above, others have argued that the Middle Horizon may represent a (second?) quantum leap in agricultural productivity, perhaps thanks to further improvements in maize strains. There is also some evidence that both the Early and Middle Horizons may have been further driven by stepchanges in 'agricultural technology': the construction of the vast arrays of terracing and irrigation that 


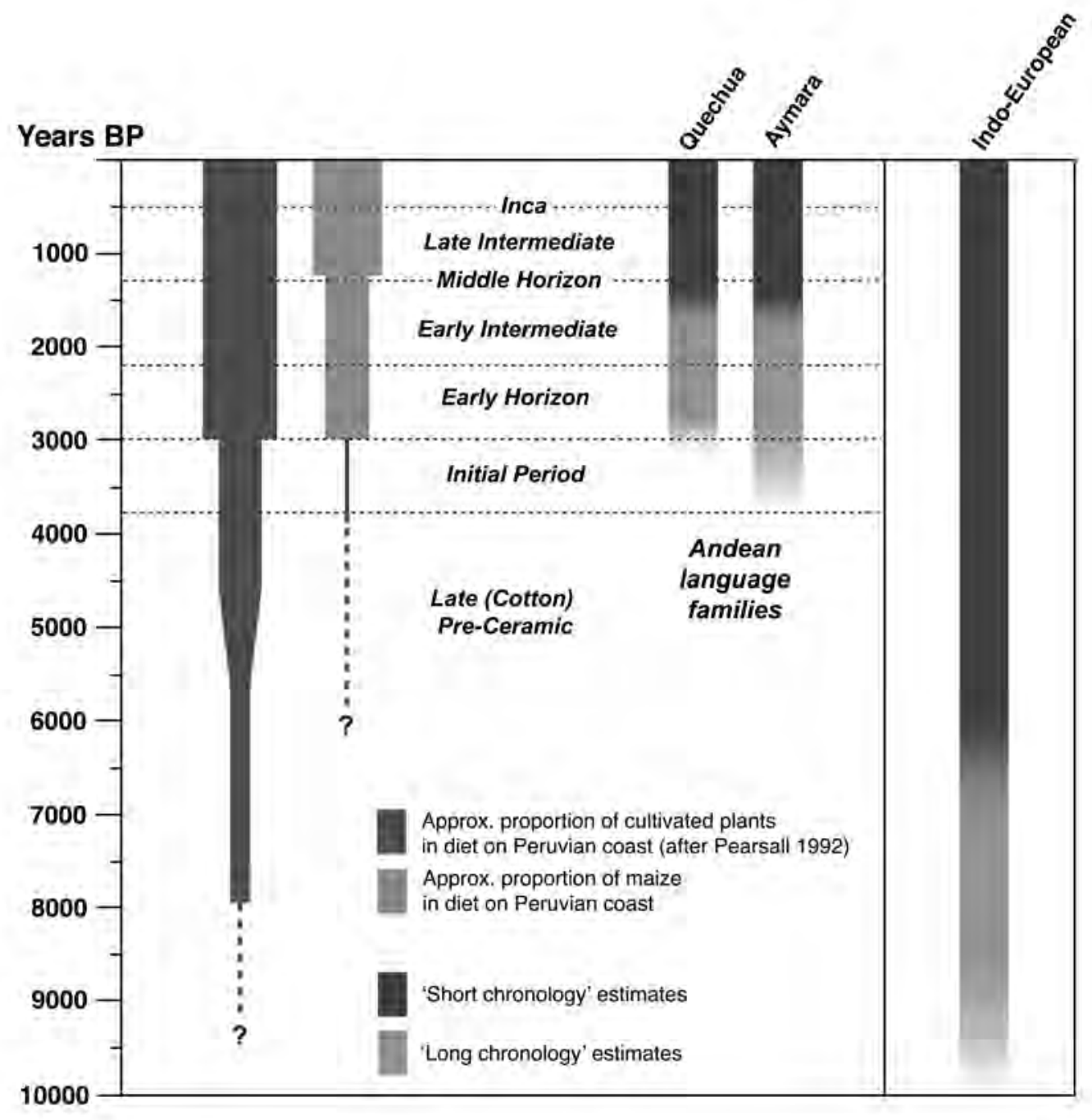

Figure 3. Language dispersals and phases of agricultural development in the Andes compared. (Figure prepared by David Beresford-Jones and Paul Heggarty.)

so characterise Andean landscapes to this day. But however concrete and material its data may seem, the archaeological record is just as open to diverse interpretation as the ostensibly more intangible data of comparative linguistics. It is no easy task to date great terracing and irrigation systems, in use and modified over extended periods. Likewise, precisely when maize attained its ultimate status as the pre-eminent Andean staple crop is still far from certain (see Burger 2012). Fortunately though, new techniques such as stable isotope analyses are continually adding to the ranges of data upon which we can make interpretations.

More widely still, the case-study of the Andes forces a thorough-going revision of the whole farming/ language dispersal hypothesis. For the Andean context demands of it key refinements which until now have simply been taken as read, because they were present more or less ab initio in how agriculture developed in the Old World context. We would suggest that for an agricultural package to confer real advantages in subsistence, it should include large domesticated animals to provide protein, as well as fertilising dung, transport, and ideally also traction for working the land — the latter a role that Andean camelids could not fulfil. Above all, the package must include a true cereal crop, as an ecologically flexible and storable 
source of starch. And to drive a major dispersal of language, an agricultural package needs also to be expansive: a "mobile food-web" (Jones 2007: 144-147) able to be propagated successfully to surrounding regions, if necessary by controlling growing seasons through agricultural technologies such as terracing and irrigation. Without these refinements taught to us by the Andean context, the region only undermines the hypothesis, as currently formulated, and the attempts to claim for it the broadest possible validity worldwide (Heggarty \& Beresford-Jones 2010, Heggarty \& Renfrew forthcoming: $\$ 4.4 .2, \$ 5.4$ ). In short, the particularities of the Andean context hold out lessons far beyond the region, and there is every reason to expect that they might do so not just for the farming/language dispersals hypothesis, but far more generally for the 'new synthesis' of the disciplines in prehistory.

In short, we would explicitly associate both the Early and Middle Horizons with step-changes in food production: two different agricultural intensification thresholds (see Pearsall 2008). What we do not advocate, of course, is a simplistic argument that the spread of the major language families of the Andes is to be sought uniquely in agriculture (see Heggarty \& Beresford-Jones 2010: 180). Both horizons were unquestionably much more than merely intensifications of maize agriculture. We shall return shortly to the debate in archaeology about the nature of each of the Andean horizons, and what our proposed 'new synthesis' of archaeology and linguistics here might mean for those debates.

\section{Not Seeing the Wood for the Trees}

There have been two partial precedents for our proposal: Isbell (1974) and Bird et al. (1984). Isbell suggested that the expansion of Quechua was associated with that of maize agriculture, though at a time-remove too great to be reconciled with linguistic data (see Cerrón-Palomino 2003: 336-8). Bird et al., meanwhile, recast Torero's original language data alongside a biogeography of maize varieties — data radically different to our own here, but arriving at a conclusion in part the same: linking the expansion of Quechua to the Middle Horizon. Neither linguists nor archaeologists have engaged meaningfully with this 'Wari as Quechua' proposal beyond merely citing it, except for Cerrón-Palomino (2000b) and Isbell (1984), respectively, both of whom are highly critical. We too disagree strongly with Bird et al.'s unorthodox vision of the linguistics, not least the disconcerting methodological liberties they take with supposed 'linguistic dating' methods. Nor does their proposal take into account the deep correspondences between Quechua and Aymara that any model needs to explain, the same omission that so undermines Browman (1994).

Certainly there were serious flaws in the linguistic argumentations of these previous proposals, then. But why is it that Andean linguists themselves have never yet entertained so straightforward a proposal of Quechua as driven by the Middle Horizon, and Aymara by the Early Horizon? The key obstacles, in our view, have been two: the traditional view of the classificatory structure of each language family as a branching tree; and the assumption that since they attest to deep contacts between each other early in their histories, they must have had their origins in territorially neighbouring homelands.

The traditional classification of the relationships between the different regional 'dialects' and languages within the Quechua envisages a 'family tree', with a series of binary branches: first the original ProtoQuechua ancestor is imagined to have split into so-called 'QI' and 'QII' branches; QII then split in turn into QIIa vs. QIIb/c; the latter then into QIIb and QIIc, and so on. (In passing, let us note and deprecate the rather loose terminology applied here: strictly, of course, the tree topology proposed should oppose a QIIa only with a QIIb, not a QIIb/c, while the latter splits only on the next level down into QIIb1, and QIIb2.) This tree model seeks to explain the various degrees of difference between modern Quechua varieties primarily in terms of greater or lesser time-depths since their respective ancestral lineages separated from each other.

In real world terms, this concept of a language 'split' typically corresponds to a stark division of an original population into two groups, thereafter no longer in contact and whose speech thus develops separately into different varieties (see Heggarty et al. 2010). So to link his branching-tree view of Quechua prehistory with the archaeological record, Torero felt compelled to seek a whole string of separate population splits and expansions by 'migration'. The result is an over-extended chronology which needs to invoke driving forces from multiple periods through Andean prehistory, and assign major roles to 
relatively minor regional polities in the Early and Late Intermediate Periods. (The same objection continues to undermine more recent proposals, such as those of Cerrón-Palomino or Adelaar in this volume.) Moreover, assuming that the Quechua and Aymara homelands must have been contiguous to each other effectively pushes Torero to hypothesise both families' origins on the coast of Peru, Quechua around Lima and Aymara further to the south. It also requires the Wari Middle Horizon to be a key second-stage driver of Aymara's expansion, ruling out a role for it in spreading Quechua instead. There are a great many infelicities in the complexities of these multiple expansion stages, and in attributing major linguistic impacts to minor polities in the archaeological record; but they are forced on the traditional model by its insistence on a branching tree as the classificatory structure of both the Quechua and Aymara language families.

It is certainly true that as an abstract intellectual model, binary branches may seem more 'elegant' — for which however read 'simple', indeed 'simplistic', in linguistic and real-world terms. For binary branches are by no means the only pattern by which languages diverge in practice. On the contrary, for many language families it is well known that no family tree classification is viable at all, and a quite different model is needed: the 'dialect continuum'. This applies to large extents of all four major language families of Europe (Romance, Germanic, Slavic and Celtic), as well as to Arabic, Bantu, Turkic, the languages of northern India, China, and elsewhere. Great swathes of human linguistic diversity cannot validly be represented by family trees, but only by dialect continua, or at most a combination of the two (Heggarty et al. 2010).

For Quechua too, the initial family-tree classification has fallen increasingly into disarray as our knowledge of the geographical diversity across the family has grown over recent decades, especially with the documentation of dialects intermediate between the supposed two main branches, or others that classify well with neither (Adelaar 1977, 1987; Taylor 1984a, 1984b). As early as Landerman (1991) it was demonstrated that the two-way QI QII split is untenable; but because he still kept faith with the tree idealisation in principle, he remained unable to offer any alternative.

To propose and justify one, more radical steps are required. Heggarty (2005) applied phylogenetic analyses of the latest, explicitly network type to new data-sets and quantification methods of his own, but also to Torero's own measures of divergence across the family. All of these consistently favour a view of Quechua not as a branching tree at all, but as a 'network' or 'web' of cross-cutting linguistic relationships - the signal typical of a dialect continuum. In short, Heggarty (2005) calls for the traditional family tree classification of a deep two-way QI QII split to be abandoned, in favour of a more continuum-like model instead. It thus remains to set this new view of Quechua's origins in a real-world context that might explain how and why the family diverged into such a pattern, if not by Torero's sequence of migrations.

In dialect continua, the respective degrees of difference between language varieties within a family are typically explained not by chronological differences in the stages at which their lineages diverged, but by degrees of coherence across a wide 'speech community', determined in large part simply by geographical distance. Classic examples are provided by Romance and, we argue, also Wari. Typically, a single ancestor language - i.e. Proto-Romance (Vulgar Latin) and Proto-Quechua in our test-cases here — is spread in what is effectively a single, contemporaneous expansion, across a continuous geographical area. If extensive enough, the various sub-regions within it will be far enough apart for the forms of speech in each naturally to diverge from each other, and all the faster after the collapse of 'political' unity across it (the fall of Rome, and of Wari). Nonetheless, local-level contacts continue, allowing new linguistic developments ('innovations') to spread by 'waves'. These come to overlap differently across different parts of the overall region, so that the original ancestor language at length turns into a dialect continuum. From one village to the next, minor differences do not disrupt mutual intelligibility; but between the distant poles of the continuum so many differences accumulate that they speak what are effectively distinct languages, albeit related. A useful analogy is a colour spectrum, where colours contrast starkly at the extremes, even if between them there is never a sharp break in the shading from red to orange to yellow to green, and so on. Within Romance, for instance, Portuguese is most similar to Spanish, then to Catalan, then Provençal, and so on the further one travels eastwards. But all these territories were settled by Latin-speakers at more or less the same time: a single, all but contemporaneous expansion with no 'splits'. We propose that a similar process is what best accounts for the core structure of the Quechua language family: an initial major expansion propelled only by the Wari Middle Horizon. 
The progressive scale of 'linguistic distance' across the Quechua 'Continuous Zone' from Áncash in the north to Cuzco in the south goes back, we argue, not to a chronological sequence of separate migrations, but merely to the greater geographical distance between them across this Quechua continuum. (Strictly, the determining factor behind this pattern is not distance per se, but the degree of coherence across what linguists term the 'speaker community'; in practice, though, geography and topography often, as in this case, stand as usefully close proxies for this.) The intermediate varieties of Yauyos (including some of the varieties classified within the much criticised 'QIIa' construct) are in their due place, in the middle of that continuum. Meanwhile, the 'unclassifiable' north Peruvian varieties (the remainder of the supposed 'QIIa'), such as the Quechua of Cajamarca, would reflect the northernmost Wari outposts, beyond the Continuous Zone and isolated from it, and which therefore developed more independently of the wave changes spreading across it (the closest Romance equivalents are the isolated 'outliers' that are Romanian and Sardinian). This scenario offers a highly plausible explanation for why Andean linguists have found these very varieties so difficult to place comfortably anywhere within the traditional Quechua family tree model.

Certainly, a dialect continuum picture can be complicated by later disruptions: political frontiers draw fault-lines within it; intermediate dialects die out or are 'standardised' towards others (especially evident in the impact of modern nation-states on the earlier dialect continua of Europe). And later expansion episodes can emerge from just points within an original continuum: just as in late Medieval times Castilian Spanish spread to the New World, so the specifically Cuzco form of Quechua dispersed to Bolivia in the Late Horizon and colonial period.

The Quechua Continuous Zone does include one internal frontier, the 'Ñawinpukyu line' between Huancayo and Huancavelica. The interpretation that this marks a discrete break between traditional 'QI' and 'QII' is somewhat overplayed and simplistic, however, and much of the explanation for it seems to go back only to the colonial era, and the labour drafts for the Huancavelica mercury mine (Pearce \& Heggarty 2011). Moreover, further west in Yauyos province the border breaks down into a more continuous 'fan' pattern from QI to QII through a dialect continuum instead. In any case, even the Nawinpukyu line by no means necessarily goes back to separate initial QI and QII migrations at different time-depths, as the traditional model would have it. The Romance language family offers a similar internal frontier, the much discussed La Spezia-Rimini line, but this is known not to reflect two very different expansion phases; rather, all Romance speech here arose out of the effectively single, continuous spread of Latin during the Roman Empire. The Nawinpukyu line likewise by no means implies two different Quechua expansion phases, rather than a single spread during the Wari Middle Horizon.

Indeed, for the core of Quechua's divergence history, our vision of a single horizon expansion in practice makes for an explanation far more economical and straightforward in real-world terms than does the supposedly 'elegant' binary tree, with its need for a string of successive migrations, first in one direction and then in others. For more on this issue of the real-world (pre-)historical correlates of dialect continua vs. branching trees, see Heggarty et al. (2010), and for the Quechua case Pearce \& Heggarty (2011).

\section{What Does It Mean for Archaeology?}

Finally we turn to the debate among archaeologists on the nature of each of the Andean 'horizons'. It is one thing, of course, to identify a 'horizon' — alias "stylistic coherence over a broad region", as Rice (1993: 9) puts it - and to describe its extent and variation in time and space as culture history wished to (difficult tasks in themselves). It is quite another to tease apart and explain, as archaeology now aspires to do, those cultural processes - economic, political, ideological, and so forth - that shaped that archaeological record. What, then, might our proposed synthesis between archaeology and linguistics contribute to this debate?

We have so far presented Wari as a military, expansionist empire, the partial consensus within Andean archaeology. But we have also alluded to how other archaeologists have nonetheless read from the same material culture record stories of the Middle Horizon that can be very different. Various primary driving forces have been invoked to account for that record, which Schreiber (2000: 443) usefully summarises as: (i) political expansion/; (ii) religion; and (iii) commerce. 
The idea that the mainspring of the Wari Middle Horizon was primarily a religious movement has a long pedigree in archaeology, dating back to Menzel herself, and is still advocated in several forms, with considerable archaeological evidence marshalled in its support (see for instance Topic \& Topic 2000). Certainly, there is little doubting the significance of religious ideology in its material culture record. Another alternative to the leading model envisages a number of independent regional polities, but linked by a substantial trading network (e.g. Shady 1982, 1989). As we have seen, it is this model that seems to underlie part of Torero's scenario for Quechua expansion, but confusingly also that of Aymara, as duly invoked by Torero in his model for language expansion - see Heggarty \& Beresford-Jones, this volume and Isbell (1984) for criticism. Such models have been advanced even more forcefully for the other pole of the Middle Horizon: Tiyawanaku, which many have interpreted as essentially a centre of pilgrimage and/ or trading emporium.

For the Early Horizon, meanwhile, sunk in far deeper recesses of Andean prehistory, speculation is lent an even freer rein. Most archaeologists see it as the expression of little more than a proselytizing cult, radiating out from (or in towards) the monumental site of Chavín de Huántar (Burger 1993, Kembel \& Rick 2004). Some would even deny its very existence as a 'Horizon' (e.g. Pozorski \& Pozorski 1987).

Here, our proposed synthesis between archaeological and linguistic data proves instructive in making an explicit claim: that whatever our interpretations of the Early and Middle Horizons, the latter, and indeed perhaps also the former, should include one or more processes capable of driving a major language expansion. This leads us in turn to question an archaeological model for either that "places the vital motor of cultural change in ideology rather than in the material realm", as Willey (1999: 86) puts it. For despite popular impressions to the contrary, on closer inspection history offers surprisingly few, if any, precedents for major language expansions driven by religion — or, for that matter, by trade.

To understand this, one must avoid confusing two utterly different linguistic realities: on the one hand, the territorial expansions of natural, changing, native-tongue language families (such as Quechua, Aymara, Romance or Indic); on the other hand, the use of a particular 'fossilised' language as an 'élite' medium of religious discourse (such as Church Latin or Classical Sanskrit), often among communities speaking various different native languages. Certainly, across Europe a fossilised form of Latin was once widespread in liturgical and scholarly uses; but even by early mediaeval times it was a learned code, the native tongue of no-one, and restricted to contexts which, for all their status, were always sociolinguistically highly marked, marginal, and ultimately doomed.

Such language uses are but an artificial side-show to the vast real-world expansion and lasting survival of the Latin lineage as living, native tongues, i.e. as the family of languages aptly named Romance (from römānicē, i.e. speaking 'in Roman'). The populations of much of modern Europe speak Romance languages not because of Christianity and its Church Latin, but because of the very temporal, pre-Christian powers of Rome and its vernacular, Vulgar Latin. Even the populations of 'Latin' America and parts of Africa who today speak Romance do so because of the later power of imperialist European empires. Christianity may have accompanied these later language expansions, but it did not empower them. On the contrary, both were driven together by other, much more material processes. Notwithstanding Europeans' appeals to Christianity to legitimise their conquests, it was not religion that provided the primary incentive in practice, nor much less conferred the key 'germs and steel' advantages that made the conquests possible at all. Similarly in India, the continued use of fossilised Sanskrit for religious and administrative purposes pales alongside the spread of the Indic family of native languages, with almost a billion native-speakers across Pakistan, Northern India and Bangladesh, derived instead from the living Prakrits.

The net linguistic effects of religions per se, even proselytizing ones, have been very modest. The one oft-cited case of a major language dispersal apparently in step with a religious one, that of Arabic and Islam, likewise turns out to be a chimera which only reinforces this principle. For again, the lasting spread of Arabic as a native language across parts of the Near East and North Africa was driven far less by religion than by one of the most crushing military conquests in history. Elsewhere, wherever the Arabs' military conquest did not reach, and even across Persia where it did, but only temporarily, their language failed to make headway except as a medium of religion discourse, and a source of loanwords into the regions' native languages. From Senegal to Sulawesi, Islamic populations continue to speak African, Indo-European and Oriental tongues — not Arabic. 
Religious ideology doubtless was an important trapping of both the Chavín Early Horizon and Wari Middle Horizon; it is certainly conspicuous in the archaeological record. Yet for all that, it signally fails as Willey's (1999: 86) "vital motor" to drive major language expansion. Perhaps archaeology has been misled by the all-too visible representation of ideology in the Andean material culture record, turning Hawkes' (1954) (in)famous 'ladder of inference' on its head.

More generally, prior to the transformations brought about by the rise of the nation state - and associated phenomena of mass education and literacy, language standardisation, transport and (tele-)communications - through most of human history mechanisms of language dispersal have been radically different to those we observe in the modern era. In this light, and as with religion, a strong case can be made that trade too is altogether too weak a driving force to explain Quechua's expansion. Until these modern transformations (and indeed arguably even since then), the sorts of contacts made through trade and exchange have had surprisingly little linguistic impact. The Phoenicians, for instance, may have dominated trade in the Mediterranean for a millennium or more, but their linguistic lineage is long extinct. Trade, like religion, has through history had far less linguistic impact than is so often superficially assumed. As a stock explanation to invoke for associations in the archaeological and linguistic records, trade too is all too facile, and smacks of instincts from our own contexts in the modern world, rather than those that prevailed through most of human (linguistic) history. (See also Heggarty \& Renfrew forthcoming: \$4.2.2.)

Indeed, this is precisely what is implied by the hypothesis — for which there is considerable linguistic support, as discussed in Heggarty \& Beresford-Jones (this volume: $\$ 1$ ) — that the language of Tiyawanaku was not Aymara, as popularly imagined, but Puquina. For the archaeological record reveals that Wari and Tiyawanaku's respective impacts beyond their own homelands were very different in nature. While Wari stamped its authority immutably on the landscape through its architecture, Tiyawanaku's influence appears far more diffuse. Both were agents of movement for goods and populations on grand scales; but whereas Wari's influence was expansive, Tiyawanaku's was largely inwards: towards its sacred ceremonial core. Linguistically too, under our model the Wari Empire drove the expansion of Quechua, one of the largest surviving native language families in the Americas, whereas the Tiyawanaku realm retains but the faintest echoes of Puquina, in the form of toponymy around Lake Titicaca and down to the Moquegua Valley.

Some authors, meanwhile, have made much of the existence of 'bilingual' or 'multilingual empires', known from historical times, to challenge the claim that, as Isbell (1984: 246) puts it, "conquest states and empires spread single languages, establishing linguistic uniformity". Empires are — by definition — multilingual at their inception, though for our purposes what matters is that they typically drive the expansion of just one language. The supposed counterexample inevitably invoked is that of the Roman Empire, which did indeed eventually split into a western Latin-speaking half, and an Eastern, predominantly Greek-speaking one. Yet this is to convey a misleading impression of Rome's linguistic impact, for over the course of its great expansion and consolidation Rome really drove just one language of empire: Latin, spread from its humble origins as but one among the patchwork of many languages of Iron Age Italy into what would ultimately turn into the vast Romance language family. Other than in administration (and ultimately, increasingly there too) the two halves of the Roman Empire were largely independent entities, not least linguistically speaking. The so-called 'Jireček Line' across the Balkans marks the sharp divide between the Latin and Greek-speaking halves, visible to this day in the inscriptions and archaeological records on either side (see Kaimio 1979). The Roman Empire was thus never a truly bilingual empire operating in, or driving the expansion of, two languages side-by-side. Greek had already been spread by earlier seaborne expansions and by Alexander, which is what made it a useful lingua franca for the Romans to avail themselves of in the east in the first place. It also assured Greek sufficient status in the face of Latin that the latter failed to spread significantly here at Greek's expense, in the way that it did successfully eclipse most languages in the West. A final key difference is that while in the west Latin was to become the everyday language of the populace and a major demographic expansion, this was never the case for either Latin or Greek in most of the already much more densely populated east; hence their very different eventual fates.

A synthesis of linguistics and archaeology has considerable implications, then, for how we interpret what the Andean 'horizons' really were. For if Wari spoke Aymara, as proposed by the traditional model, 
then the modesty of its linguistic legacy across the Central Andes - toponymy and a few scattered pockets of speakers - fits rather ill with the model of a military expansionist empire establishing direct control over vast territories, in the manner of the Incas or the Romans. If, on the other hand, our new proposal is correct and Wari spoke Quechua, then the model of direct control is all but required in order to account for its linguistic impact. (The fainter surviving trace of Aymara's expansion across the Central Andes might then be explained by the greater time-depth — and relatively weaker impact? — of the Early Horizon.) But whichever it is, the traditional model or our new proposal: either way the synthesis of archaeology and linguistics illuminates our understanding of this crucial period of Andean prehistory in a hitherto unexplored way.

\section{Conclusions}

By their very nature, interdisciplinary syntheses run a risk of circularity. One model, weakly substantiated in one discipline, is invoked to bolster its counterpart model in the other; which then, by definition, feeds back to support the first: "building on each other's myths", as Renfrew (1987: 287) aptly puts it. Such dangers lurk in the forests of phylogenetic trees proposed for human genetic and linguistic lineages — not least the match for all of humanity proposed by Cavalli-Sforza (1997: Fig. 3), infamous among linguists as linguistically simplistic and invalid. The archaeological interpretations that many of the trees appeal to likewise turn out to be equally questionable.

The distinction between a coherent picture across the disciplines, and a 'just-so' story based on circular argument, can lie ultimately only in judgements passed independently in each discipline on the strength of the data and their interpretations. Here this includes the case for abandoning an outdated and inappropriate tree-only model of how Quechua came to occupy the Continuous Zone, through a sequence of splits and independent migrations, and replacing it with an acceptance that the real linguistic patterns are not so discrete, and could just as well have emerged from a single major expansion phase.

The risks can be mitigated also through the principled new methodology we propose: seeking to correlate the disciplines independently on each of our three levels of chronology, geography and causation. Of the three, however, as we set sail for any 'new synthesis' goal, it is causation that stands as mast and sail, with the other levels adding little more than ropes and rigging. Links between our archaeological and linguistic records of the past should first and foremost be cast in terms of those same forces that affect human populations, and to which both those records attest; and they must be coherent above all in the commensurate scale of their impacts in each.

As culture history fell out of favour and the material record came to be viewed through the processual lens of culture evolution, archaeology lost some of its perspective on those appropriate scales. Unfortunately so, for a principled synthesis of the archaeological and linguistic stories has great potential to enrich our understanding of prehistory. Moreover, for all the semantic elaborations of more recent archaeological theory, in the case of the Andes the current leading model of the Wari Middle Horizon turns out to be no different in essence to that founded by the culture-historical work of Rowe and Menzel (e.g. Rowe 1956, Menzel 1967). The Wari 'Empire' fell only for the 'state' to be built upon its theoretical ruin. Our own proposal strengthens still further the interpretation of the Wari phenomenon as akin to that of the Incas: an expansionist, military conquest empire, based also on an intensification of agricultural production, thanks to its ability to co-opt large labour forces for great public works to build terracing, irrigation systems, the road network, and so on. To the many elements of 'Inca' statecraft that archaeology has gradually revealed to have had their roots in the lost empire of the Middle Horizon, we now propose to add one more: the expansion of the greatest surviving language family of the New World, Quechua. 


\section{Notes}

${ }^{1}$ An earlier version of this article appeared in Archaeology and Language in the Andes (2012), edited by P. Heggarty \& D. G. Beresford-Jones, pp. 55-82, Proceedings of the British Academy 173, Oxford University Press, London.

${ }^{2}$ When I consider well, most illustrious Queen, and set before my eyes the antiquity of all the things which remain written down for our record and memory, one thing I find and draw as a most certain conclusion, that always language was the companion of empire, and followed it in such a way that jointly they began, grew, flourished; and afterwards joint was the fall of both. (Cited and translated by Ostler 2006: 331.)

${ }^{3}$ We prefer this spelling as closer to the original indigenous pronunciation, restoring the second syllable -ya-suggested both by etymology and by the original Hispanicised version Tiahuanaco (but omitted from the popular modern Tiwanaku).

\section{REFERENCES}

Adelaar, W. F. H.

1977 Tarma Quechua, Grammar, Texts, Dictionary, Peter de Ridder Press, Lisse.

1987 Morfología del quechua de Pacaraos, Universidad Nacional Mayor de San Marcos, Lima.

1995 Raíces lingüísticas del quichua de Santiago del Estero, in: A. Fernández Garay \& J. P. Viegas Barros (eds.), Actas de las Segundas Jornadas de Lingüistica Aborigen, 15 al 18 de noviembre de 1994, 22-50, Facultad de Filosofía y Letras, Instituto de Lingüística, Universidad de Buenos Aires, Buenos Aires.

2012 Cajamarca Quechua and the Expansion of the Huari State, in: P. Heggarty \& D. G. Beresford-Jones (eds.), Archaeology and Language in the Andes, 197-217, Proceedings of the British Academy 173, Oxford University Press, London.

Adelaar, W. F. H., with the collaboration of P. C. Muysken

2004 The Languages of the Andes, Cambridge University Press, Cambridge.

Benavides, $\mathrm{M}$.

1991 Cheqo Wasi, Huari, in: W. H. Isbell \& G. F. McEwan (eds.), Huari Administrative Structure: Prehistoric Monumental Architecture and State Government, 55-70, Dumbarton Oaks Research Library and Collection, Washington, D.C.

Bird, R. M., D. L. Browman \& M. E. Durbin

1984 Quechua and Maize: Mirrors of Central Andean Culture History, Journal of the Steward Anthropological Society 15 $(1-2), 187-240$.

Boone, E.

1993 Preface, in: D. S. Rice (ed.), Latin American Horizons: A Symposium at Dumbarton Oaks, 11th and 12th October 1986, vii-viii, Dumbarton Oaks Research Library and Collection, Washington, D.C.

Browman, D. L.

1994 Titicaca Basin Archaeolinguistics: Uru, Pukina and Aymara AD 750-1450, World Archaeology 26 (2), 235-251.

Burger, R. L.

1993 The Chavín Horizon: Stylistic Chimera or Socioeconomic Metamorphosis?, in: D. S. Rice (ed.), Latin American Horizons: A Symposium at Dumbarton Oaks, 11th and 12th October 1986, 41-82, Dumbarton Oaks Research Library and Collection, Washington, D.C.

2012 Central Andean Language Expansion and the Chavín Sphere of Interaction, in: P. Heggarty \& D. G. BeresfordJones (eds.), Archaeology and Language in the Andes, 133-159, Proceedings of the British Academy 173, Oxford University Press, London. 
Cavalli-Sforza, L. L.

1997 Genes, Peoples, and Languages, Proceedings of the National Academy of Sciences of the United States of America 94 (15), 7719-7724.

Cerrón-Palomino, R.

1998 El cantar de Inca Yupanqui y la lengua secreta de los incas, Revista Andina 32, 417-452.

1999 Tras las huellas del aimara cuzqueño, Revista Andina 33, 137-161.

2000 Lingüistica aimara, Biblioteca de la Tradición Oral Andina 21, Centro de Estudios Regionales Andinos Bartolomé de Las Casas, Cuzco.

2001 El origen centroandino del aimara, in: P. Kaulicke \& W. H. Isbell (eds.), Huari y Tiwanaku: modelos vs. evidencias. Primera parte, Boletín de Arqueología PUCP 4 (2000), 131-142.

2003 Lingüistica quechua, 2nd ed., Centro de Estudios Regionales Andinos Bartolomé de Las Casas, Cuzco.

2005 El aimara como lengua oficial de los incas, in: P. Kaulicke, G. Urton \& I. Farrington (eds.), Identidad y transformación en el Tawantinsuyu y en los Andes coloniales. Perspectivas arqueológicas y etnohistóricas. Tercera parte, Boletin de Arqueología PUCP 8 (2004), 9-21.

2008 Voces del Ande: ensayos sobre onomástica andina, Pontificia Universidad Católica del Perú, Lima.

2012 Unravelling the Enigma of the 'Particular Language' of the Incas, in: P. Heggarty \& D. G. Beresford-Jones (eds.), Archaeology and Language in the Andes, 265-294, Proceedings of the British Academy 173, Oxford University Press, London.

Conklin, W. J.

1991 Tiahuanaco and Huari: Architectural Comparisons and Interpretations, in: W. H. Isbell \& G. F. McEwan (eds.), Huari Administrative Structure: Prehistoric Monumental Architecture and State Government, 281-292, Dumbarton Oaks Research Library and Collection, Washington, D.C.

Cook, A. G.

2004 Wari Art and Society, in: H. I. Silverman (ed.), Andean Archaeology, 146-166, Blackwell Studies in Global Archaeo$\log$ 2, Blackwell, Malden.

D'Altroy, T. N. \& K. Schreiber

2004 Andean Empires, in: H. I. Silverman (ed.), Andean Archaeology, 255-279, Blackwell Studies in Global Archaeology 2, Blackwell, Malden.

DeMarrais, E.

2012 Quechua's Southern Boundary: The Case of Santiago del Estero, Argentina, in: P. Heggarty \& D. G. BeresfordJones (eds.), Archaeology and Language in the Andes, 375-408, Proceedings of the British Academy 173, Oxford University Press, London.

Glowacki, M. L.

2002 The Huaro Archaeological Site Complex: Rethinking the Huari Occupation of Cuzco, in: W. H. Isbell \& H. I. Silverman (eds.), Andean Archaeology. Vol. I, Variations in Sociopolitical Organization, 267-286, Kluwer Academicl Plenum Publishers, Springer, New York.

Godelier, M.

1977 The Concept of 'Social and Economic Formation': The Inca Example, in: Perspectives in Marxist Anthropology, 63-69, Cambridge University Press, Cambridge.

Grobman, A., W. Salhuana, R. Sevilla in collaboration with P. C. Mangelsdorf

1961 Races of Maize in Peru. Their Origins, Evolution and Classification, National Research Council Publication 915, National Academy of Sciences, Washington, D.C.

Hawkes, C. F.

1954 Archaeological Theory and Method: Some Suggestions from the Old World, American Anthropologist, New Series, 56 (2), 155-168. 
Heggarty, P.

2005 Enigmas en el origen de las lenguas andinas: aplicando nuevas técnicas a las incógnitas por resolver, Revista Andina 40,9-57.

2007 Linguistics for Archaeologists: Principles, Methods and the Case of the Incas, Cambridge Archaeological Journal 17 (3), 311-340.

2008 Linguistics for Archaeologists: A Case-Study in the Andes, Cambridge Archaeological Journal 18 (1), 35-56.

Heggarty, P. \& D. G. Beresford-Jones

2010 Agriculture and Language Dispersals: Limitations, Refinements, and an Andean Exception? Current Anthropology 51 (2), 163-191.

\section{Heggarty, P., W. Maguire \& A. McMahon}

2010 Splits or Waves? Trees or Webs? How Divergence Measures and Network Analysis can unravel Language Histories, in: J. Steele, P. Jordan \& E. Cochrane (eds.), Philosophical Transactions of the Royal Society of London. Series B, Biological Sciences. Special Theme Issue: Cultural and Linguistic Diversity: Evolutionary Approaches 365 (1559), 3829-3843.

\section{Heggarty, P. \& C. Renfrew}

forth- Introduction: Languages, in: C. Renfrew \& P. Bahn (eds.), The Cambridge World Prehistory, Cambridge Univercoming sity Press, Cambridge.

Hiltunen, J. J. \& G. F. McEwan

2004 Knowing the Inca Past, in: H. I. Silverman (ed.), Andean Archaeology, 237-254, Blackwell Studies in Global Archaeology, Blackwell, Malden.

\section{Hocquenghem, A.-M.}

2012 How did Quechua reach Ecuador?, in: P. Heggarty \& D. G. Beresford-Jones (eds.), Archaeology and Language in the Andes, 345-373, Proceedings of the British Academy 173, Oxford University Press, London.

\section{Howard, R.}

2011 The Quechua Languages in the Andes Today: Between Statistics, the State, and Daily Life, in: P. Heggarty \& A. J. Pearce (eds.), History and Language in the Andes, 189-213, Studies of the Americas, Palgrave Macmillan, London.

Isbell, W. H.

1974 Ecología de la expansión de los quechuahablantes, Revista del Museo Nacional 34, 143-197.

1984 Andean Linguistics and Culture History: An Examination of Competing Interpretations, Journal of the Steward Anthropological Society 15 (1-2), 241-258.

1987 State Origins in the Ayacucho Valley, Central Highlands, Peru, in: J. Haas, S. G. Pozorski \& T. G. Pozorski (eds.), The Origins and Development of the Andean State, 83-90, New Directions in Archaeology, Cambridge University Press, Cambridge.

1988 City and State in Middle Horizon Wari, in: R. W. Keatinge (ed.), Peruvian Prehistory: An Overview of Pre-Inca and Inca Society, 164-189, Cambridge University Press, Cambridge.

2001 Repensando el Horizonte Medio: el caso de Conchopata, Ayacucho, Perú, in: P. Kaulicke \& W. H. Isbell (eds.), Huari y Tiwanaku: modelos vs. evidencias. Primera parte, Boletin de Arqueología PUCP 4 (2000), 9-68.

2012 Middle Horizon Imperialism and the Prehistoric Dispersal of Andean Languages, in: P. Heggarty \& D. G. Beresford-Jones (eds.), Archaeology and Language in the Andes, 219-245, Proceedings of the British Academy 173, Oxford University Press, London.

Isbell, W. H., C. Brewster-Wray \& L. E. Spickard

1991 Architecture and Spatial Organization at Huari, in: W. H. Isbell \& G. F. McEwan (eds.), Huari Administrative Structure: Prehistoric Monumental Architecture and State Government, 19-55, Dumbarton Oaks Research Library and Collection, Washington, D.C. 
Isbell, W. H. \& P. J. Knobloch

2008 Missing Links, Imaginary Links: Staff God Imagery in the South Andean Past, in: W. H. Isbell \& H. I. Silverman (eds.), Andean Archaeology III: North and South, 307-351, Kluwer Academic/Plenum Publishers, Springer, New York.

Isbell, W. H. \& A. N. Vranich

2004 Experiencing the Cities of Wari and Tiwanaku, in: H. I. Silverman (ed.), Andean Archaeology, 167-182, Blackwell Studies in Global Archaeology, Blackwell, Malden/Oxford.

Jones, M. K.

2007 Feast: Why Humans Share Food, Oxford University Press, Oxford.

Kaimio, J.

1979 The Romans and the Greek Language, Commentationes Humanarum Litterarum 64, Societas Scientiarum Fennica, Helsinki.

Kembel, S. R. \& J. W. Rick

2004 Building Authority at Chavín de Huántar: Models of Social Organization and Development in the Initial Period and Early Horizon, in: H. I. Silverman (ed.), Andean Archaeology, 51-76, Blackwell Studies in Global Archaeology, Blackwell, Cambridge.

Landerman, P. N.

1991 Quechua Dialects and their Classification, Ph.D. dissertation, University of California at Los Angeles, UMI Dissertation Services, Ann Arbor.

Lumbreras, L. G.

1974 The Peoples and Cultures of Ancient Peru [translated by B. Meggers], Smithsonian Institution Press, Washington, D.C.

McEvedy, C.

1992 The Penguin Atlas of Medieval History, Penguin, London.

McEwan, G. F.

1991 Investigations at the Pikillacta Site: A Provincial Huari Center in the Valley of Cuzco, in: W. H. Isbell \& G. F. McEwan (eds.), Huari Administrative Structure: Prehistoric Monumental Architecture and State Government, 93119, Dumbarton Oaks Research Library and Collection, Washington, D.C.

2012 Indicators of Possible Driving Forces for the Spread of Quechua and Aymara Reflected in the Archaeology of Cuzco, in: P. Heggarty \& D. G. Beresford-Jones (eds.), Archaeology and Language in the Andes, 247-263, Proceedings of the British Academy 173, Oxford University Press, London.

Menzel, D.

1967 Style and Time in the Middle Horizon, in: J. H. Rowe \& D. Menzel (eds.), Peruvian Archaeology: Selected Readings, 146-164, Peek, Palo Alto.

Moseley, M. E., R. A. Feldman, P. S. Goldstein \& L. Watanabe

1991 Colonies and Conquest: Tiahuanaco and Huari in Moquegua, in: W. H. Isbell \& G. F. McEwan (eds.), Huari Administrative Structure: Prehistoric Monumental Architecture and State Government, 121-140, Dumbarton Oaks Research Library and Collection, Washington, D.C.

Muysken, P. C.

2012 Modelling the Quechua-Aymara Relationship: Structural Features, Sociolinguistic Scenarios, and Possible Archaeological Evidence, in: P. Heggarty \& D. G. Beresford-Jones (eds.), Archaeology and Language in the Andes, 83-107, Proceedings of the British Academy 173, Oxford University Press, London.

Ostler, N.

2006 Empires of the Word: A Language History of the World, Harper Collins, London.

Pearce, A. J. \& P. Heggarty

2011 'Mining the Data' on the Huancayo-Huancavelica Quechua Frontier, in: P. Heggarty \& A. J. Pearce (eds.), History and Language in the Andes, 117-146, Studies of the Americas, Palgrave Macmillan, London.

Pearsall, D. M.

2008 Plant Domestication and the Shift to Agriculture in the Andes, in: H. I. Silverman \& W. H. Isbell (eds.), Handbook of South American Archaeology, 105-120, Springer, New York. 


\section{Pozorski, S. G. \& T. G. Pozorski}

1987 Early Settlement and Subsistence in the Casma Valley, Peru, University of Iowa Press, Iowa City.

Renfrew, C.

1987 Archaeology and Language: The Puzzle of Indo-European Origins, Jonathan Cape, London.

1989 World Languages and Human Dispersals: A Minimalist View, in: J. A. Hall (ed.), Transition to Modernity, 11-68, Cambridge University Press, Cambridge.

2012 Archaeology and Language in the Andes: Some General Models of Change, in: P. Heggarty \& D. G. BeresfordJones (eds.), Archaeology and Language in the Andes, 41-54, Proceedings of the British Academy 173, Oxford University Press, London.

Rice, D. S.

1993 The Status of Latin American Horizons, in: D. S. Rice (ed.), Latin American Horizons: A Symposium at Dumbarton Oaks, 11th and 12th October, 1986, 357-364, Dumbarton Oaks Research Library and Collection, Washington, D.C.

Rowe, J. H.

1956 Archaeological Explorations in Southern Peru, 1954-1955: Preliminary Report of the Fourth University of California Archaeological Expedition, American Antiquity 22 (2), 135-151.

Schreiber, K. J.

1992 Wari Imperialism in Middle Horizon Peru, Anthropological Papers 87, Museum of Anthropology University of Michigan, Ann Arbor.

2001 Los wari en su contexto local: Nasca y Sondondo, in: P. Kaulicke \& W. H. Isbell (eds.), Huari y Tiwanaku: modelos vs. evidencias. Primera parte, Boletín de Arqueología PUCP 4 (2000), 425-447.

Shady, R.

1982 La cultura Nievería y la interacción social en el mundo andino en la época Huari, Arqueológicas 19, 5-108.

1989 Cambios significativos ocurridos en el mundo andino durante el Horizonte Medio, in: R. M. Czwarno, F. M. Meddens \& A. Morgan (eds.), The Nature of Wari: a Reappraisal of the Middle Horizon Period in Perú, 1-22, BAR International Series 525, Oxford.

Silverman, H. I.

2004 Introduction: Space and Time in the Central Andes, in: H. I. Silverman (ed.), Andean Archaeology, 1-15, Blackwell Studies in Global Archaeology, Blackwell, Oxford.

Sutter, R. C.

2009 Prehistoric Population Dynamics in the Andes, in: J. Marcus y P. R. Williams (eds.), Andean Civilization: A Tribute to Michael E. Moseley, 9-38, Monograph 63, Cotsen Institute of Archaeology Press, University of California at Los Angeles, Los Angeles.

Taylor, G. F.

$1984 a$ Yauyos, un microcosmo dialectal quechua, Revista Andina 3, 121-46.

$1984 \mathrm{~b}$ Estudios de dialectología quechua (Chachapoyas, Ferreñafe, Yauyos), Textos Universitarios, Universidad Nacional de Educación Enrique Guzmán y Valle, Lima.

Topic, J. R. \& T. L. Topic

2001 Hacia la comprensión del fenómeno huari: una perspectiva norteña, in: P. Kaulicke \& W. H. Isbell (eds.), Huari y Tiwanaku: modelos vs. evidencias. Primera parte, Boletín de Arqueología PUCP 4 (2000), 181-217.

Torero, A.

2002 Idiomas de los Andes: lingüistica e historia, Travaux de l'Institut Français d'Études Andines 162, Instituto Francés de Estudios Andinos, Horizonte, Lima.

Tung, T. A. \& B. D. Owen

2008 Violence and Rural Lifeways at Two Peripheral Wari Sites in the Majes Valley of Southern Peru, in: W. H. Isbell \& H. I. Silverman (eds.), Andean Archaeology III: North and South, 435-467, Kluwer Academic,/Plenum Publishers, Springer, New York. 
Urton, G.

2012 The Herder-Cultivator Relationship as a Paradigm for Archaeological Origins, Linguistic Dispersals and the Evolution of Record Keeping in the Andes, in: P. Heggarty \& D. G. Beresford-Jones (eds.), Archaeology and Language in the Andes, 321-343, Proceedings of the British Academy 173, Oxford University Press, London.

Watanabe, S.

2002 Wari y Cajamarca, in: P. Kaulicke \& W. H. Isbell (eds.), Huari yTiwanaku: modelos vs. evidencias. Segunda parte, Boletín de Arqueología PUCP 5 (2001), 531-541.

Willey, G. R.

1951 The Chavín Problem: A Review and Critique, Southwestern Journal of Anthropology 7 (2), 103-144.

1999 Styles and State Formations, Latin American Antiquity 10 (1), 86-90.

Williams, P. R.

2001 Cerro Baúl: a Wari Center on the Tiwanaku Frontier, Latin American Antiquity 12 (1), 67-83.

Williams, P. R. \& D. J. Nash

2002 Imperial Interaction in the Andes: Huari and Tiwanaku at Cerro Baúl, Iwawi and Tiwanaku, in: H. I. Silverman \& W. H. Isbell (eds.), Andean Archaeology. Vol. I, Variations in Sociopolitical Organization, 199-242, Kluwer Academic/Plenum Publishers, Springer, New York. 